\title{
The Sacralization of the Myth of Prohibition of Leaving the House at Dusk in Sandekala Film: Charles Sanders Pierce's Semiotic Analysis
}

\author{
Asna Istya Marwantika \\ Institut Agama Islam Negeri (IAIN) Ponorogo \\ marwantika@iainponorogo.ac.id
}

Received: Oct 16, 2020 | Revised: Feb 22, 2021 | Approved: April 12, 2021

\begin{abstract}
Sandekala is a horror film that tells the story of local and religious myths about the prohibition of going out at dusk because the devil hovers around at this time. The combination of myth and religion in this horror film is also an attempt to sacralize myth and religion produced in the plot of a scary film scene. This study aims to determine the position of myth and religious themes in the horror film genre in Indonesia and discuss how the sacred depiction of the myth of the prohibition of leaving at dusk. Sandekala's film was analyzed using Charles Sanders Peirce's semiotic analysis, namely sign, text, and interpretant. The results of this study are that first, Indonesian horror filmmakers have used myth and religion since the New Order until now. Second, the depiction of the sacredness of the myth of the prohibition of going out at sunset in this film with a dark evening scene, the mother and child as the main characters who have left the house at dusk ignoring the prohibition that has become a myth of society. In addition to confirming society's myth, this film is also an effort to remind the segmentation of young people and urbanites who have begun to forget this myth.
\end{abstract}

Keywords: Sacralization of Myth, Semiotic Analysis, Sandekala Film

\begin{abstract}
Abstrak: Film Sandekala merupakan film bergenre horor yang bercerita mengenai mitos lokal dan religi tentang larangan keluar rumah pada waktu magrib karena setan bergentayangan pada waktu ini. Gabungan antara mitos dan religi dalam film horor ini juga merupakan upaya sakralisasi antara mitos dan religi yang diproduksi dalam alur scene film yang menakutkan. Penelitian ini bertujuan untuk mengetahui posisi tema mitos dan religi dalam genre film horor di Indonesia, dan membahas tentang bagaimana penggambaran sakralisasi mitos larangan keluar pada waktu magrib. Fim Sandekala dianalisis menggunakan analisis semiotik Charles Sanders Peirce yaitu sign, teks dan interpretant. Hasil dari penelitian ini adalah pertama, tema mitos dan religi sudah digunakan sineas film horor Indonesia sejak Era Orde Baru sampai sekarang ini. Kedua, penggambaran sakralisasi mitos larangan keluar magrib di film ini dengan scene suasana magrib yang gelap, ibu dan anak sebagai pemeran utama yang terlanjur keluar rumah waktu magrib ini mengabaikan larangan yang sudah menjadi mitos masyarakat. Film ini selain meneguhkan mitos masyarakat, juga sebagai upaya untuk mengingatkan segmentasi anak muda dan kaum urban yang sudah mulai melupakan mitos ini.
\end{abstract}

Kata kunci: Analisis Semiotik, Film Sandekala, Sakralisasi Mitos 
The Sacralization of the Myth...

Marwantika 2021

\section{Introduction}

Dusk (magrib), which is the time of movement from day to night, is sacred to Indonesian people through the myth of not being allowed to leave the house because demons and jinn roam. Amriy Ramadhan later adapted the myth that developed in this society in the film Sandekala. Sandekala is a short film category with 9 minutes and 3 seconds and has won seven national and international award categories (FilmFest, 2016). This horror-genre short film manages to combine the sacredness of the dusk myth through dark visualization, gripping sound effects, and quite effective scene transitions.

So far, horror films tend to exploit fear, horror, and explore things related to beliefs and absurdities about something. When viewed from the Hollywood (AmericanEuropean) production, the themes of horror films that have been presented from the 1930s to the present include myths, psychology, extraterrestrials, serial killers, and local myths or legends (Yoesoef, 2015). Meanwhile, horror film themes circulating in Indonesia from 1970 to the New Order era include spirits, local myths, mystery stories, and curious spirits (Nur, 2016). The post-reform era was marked by the increasing number of horror films but more peppered with myths (Agustina, 2016), pornography (Herawati, 2011), and sensuality (Ayun, 2015).

The Sandekala film analyzed in this study combines myth and religious themes. Myth and religion are themes that can be used or adapted into a film genre. These two things are only used as commodities, but myths have dominated the theme of horror films in Indonesia. Meanwhile, religious themes are also featured in horror films according to (Hakim, 2017, p. 6) with the involvement of Islamic religious symbols, such as the presence of a kyai who drives out demons with scenes of reciting verses from the Koran, and also using prayer beads as accessories of kyai to cast out demons. This scene of the kyai exorcist is seen in the films Sundel Bolong (third nominee in Indonesia in 1981), Nyi Blorong (first nomination in 1982), Kisah Cinta Nyi Blorong (fourth in 1987), Buaya Putih, and Ratu Pantai Selatan. Apart from that, both films and soap operas with the theme of religion also involve mystical elements, stories of astral and supernatural beings. This can be seen in the films "Sunan Kalijaga and Syech Siti Jenar" (1985), "Fatahillah" (1997), along with the soap operas "Secret Divine" (2004-2007), "Pintu Hidayah" (2005-2007), and "Azab". (2018-2019). 
The correlation between film and religion, according to (Watkins 2008, p. 224), contains four things. First, the use of religion for film interpretation. The use of religion for film interpretation is understood as the ideology used to interpret films, such as in the film "The Matrix" (1999) which tells the relationship between Thomas Anderson's character and Jesus.

In Indonesia, it is like the film of "Mencari Hilal" (2015), and "Haji Backpacker" (2014). Second, the use of films to criticize religion such as "Priest" (1994), "Passion of Christ" (2004), "Last Temptation of Christ" (1988), and "Agnes of God" (1985). Whereas in Indonesia, the titles of films which are included in the theme of criticizing religion are "Doa yang Mengancam" (2008), "Perempuan Berkalung Sorban" (2009), also the film "?" (2011). Third, the use of films to present religions with cultural values such as "99 Cahaya di Langit Eropa" (2013). Fourth, films with the theme of motivation and encouraging religious life (religion uses the movies), such as the film of "3 Doa 3 Cinta" (2008), and "3 Hati 2 Dunia 1 Cinta” (2010).

In the relationship between film and religion, Gregory J Watkins places Sandekala as a film that displays religion as cultural values. Religion is in a sacred area while culture occupies a profane locus. The sacred area in Sandekala is an attempt to translate the myth of not leaving the house at dusk based on the hadith of the Prophet Muhammad narrated by Imam Bukhari and Imam Muslim (Farizal Alam, 2018, p.109) with the following translation;

"If the night comes, or you are in the evening, then hold on to your children, because actually at that time the devils are scattering. If a moment has passed from the time of night, then let them go. Close the door and do dhikr to Allah because Satan cannot open a closed door. Also, close your drink and food containers and make dhikr to Allah, even if you just put something down."

Meanwhile, the profane area in this film is described in the form of a myth about the prohibition of leaving the house when the sunsets. This myth is a speech culture that exists in Javanese and Sundanese culture. " Yen Waktu Magrib aja Metu saka Omah Mundhak Ono Sambikolo " (Farizal Alam, 2018); this expression is a culture of speech with the meaning of the devil/genie that is believed by the community to frighten children, so they do not hang around at night. This myth, by the Javanese, is neatly wrapped/packaged with the meaning that emerges from the local cultural wisdom so that the Javanese people more readily accept it.

This paper is based on the argument that horror films in Indonesia are produced with themes of myth, astral creatures, sensuality, pornography and religion because 
they are profitable in terms of the film industry and are well responded to by the public (cnbcindonesia.com, 2019; cnnindonesia.com, 2019; Marwantika, 2019). The film Sandekala with the theme of myths wrapped in religion is analyzed using Charles Sanders Peirce's semiotic analysis to find out how the sacralization of the packaging of the two themes is described in this Sandekala film.

\section{Methods}

Research on films is executed using a qualitative approach (Ida, 2014; Kriyantono, 2014). The research on the sacredness of the myth of the prohibition to leave the house at dusk in the film of Sandekala is qualitative research based on the analysis of the film. The data source used is documentation in the form of a video of the short film of Sandekala on Youtube media. From these data, the appropriate symbol that describes the sacred myth of sunset is observed, sorted, and finally selected.

The data processing technique goes through four stages: a) seeing the short film Sandekala downloaded earlier on the SnapfilmID youtube channel, b) observing every scene in the film, starting from the background, expressions, and the narrative used. c) doing screen capture on every shooting scene/scene considered to represent the sacred theme of sunset, d) analyzing the data with Charles Sanders Peirce's analysis to determine the sacredness of myths in the Sandekala film. The process of analyzing data in this process is by examining all data obtained from various sources. Next, the data are reduced, interpreted, and processed through concluding using the Charles Sanders Peirce model of semiotics analysis.

Peirce's Semiotics offers the concept of trichotomy / triadic, which consists of (Sobur, 2008, p. 98); (1) representamen; namely the form accepted by the sign or function as a sign, (2) interpretant; namely the meaning of the sign, or more refers to the meaning of (3) object; that is, something that refers to a sign. Peirce's triadic model is often called the "triangle meaning semiotics" or triangle meaning theory. If explained simply, a sign is something that is attributed to a person in several ways. Interpretant or sign user interprets a particular meaning after observing the object referred to from a sign. At the same time, the object is a sign that is displayed by the reality of the media.

Peirce's semiotic classification consists of ground, object and interpretant (Wahyuningsih, 2019, p. 76). First, the ground is divided into three, namely qualisign, sinsign and legisign. Qualisign is a quality that is in the sign; for example words are 
harsh, loud, soft, melodious. Sinsign is the existence of objects or events in the sign, for example the word fuzzy or cloudy which is in the order of the word cloudy river water which indicates that there is rain in the upper reaches of the river. Legisign is a norm that a sign contains, for example, traffic signs that indicate what humans can and cannot do. Second, objects are divided into icons, indexes and symbols. Icons are similar objects and give messages in their original form.

Meanwhile, the index is a sign that is a cause-effect or causality relationship. Symbols are signs associated with markers and markers. Third, the interpretant consists of three; namely a) rheme, a sign that can be interpreted in different meanings, b) Dicent sign or dicisign a sign that follows reality/facts, c) argument, which is a sign that contains something/reality.

\section{Discussion}

\section{The Journey of Horror Films in Indonesia}

Horror films in Indonesia have gone through three periods, first the Dutch Colonial Era, the second the New Order, and the third the Post-Reform Era. These three periods also carry the consequences of different themes, different audience segmentations, and bring different financial benefits as well. The first period, the Dutch Colonial Period, according to (Yoesoef, 2015, p. 13) horror films in Indonesia were introduced in 1930, namely "Doea Siloeman Oeler Poeti en Item" in 1943, then the film of "Tie Pat Kai Kawin Siloeman Babi Perang Siloeman Monjet", the film "Anaknja Siloeman Oeler Poeti "in 1936, as well as the film" 5 Siloeman Tikoes "in 1936. (Yoesoef, 2015). This period of horror film carried the theme of stealth from Chinese legends.

The second period, the New Order, the horror films made by Indonesian filmmakers during the New Order era were "Lisa" and "Beranak Dalam Kubur". The success of the two films then influenced filmmakers to make horror films with the theme of local myths such as Nyi Roro Kidul, Kuntilanak, Sundel Bolong, Tuyul, Pocong, or Jelangkung. During the 1970s, 22 titles were produced. In the 1980s, there were 78 film titles, and this was marked as the golden age of horror films in Indonesia, Suzanna Martha Frederika was an icon of horror films in those years. The film, starring Suzanna, was included in the Top Five Box Office category and received a good response from the audience, such as "Sangkuriang" (1983), "Nyi Ageng Ratu Pemikat" (1985), "Telaga Angker" (1986), "Santet" (1989). ) and "Ratu Buaya" (1989). Furthermore, horror films 
in the 1990s experienced a production crisis marked by a decline in the number of film titles and many production houses collapsed due to the expansion and monopoly of foreign films in Indonesia, in addition to the economic crisis that forced horror film production to enter a period of hibernation in 1998 (Agustina, 2016).

The third period, in the post-reform era, was marked by the presence of the film of Jaelangkung (2001) by Jose Purnomo and Rizal Mantovani which received 1.5 million. Of national audiences. This Jelangkung film proves there is still public enthusiasm for horror films, after previously experiencing a period of vacuum and hibernation after being hit by the economic crisis. The horror films produced from 2001 and above have undergone a process of market segmentation changes and location settings changes. This market segmentation which targets young people then requires filmmakers to choose horror film actors from young artists who are also shown as urban society, from the middle class and technology literate but have a sense of curiosity and an escape from mystical things. Meanwhile, the location setting has also changed from the beginning of the film during the New Order Era to prefer a rural setting. However, during the Postreform era it shifted more to urban areas, close to the center of the economy and entertainment. Films with urban settings such as "Terowongan Casablanca", "Taman Lawang", "Mall Klender", all of them employ Jakarta setting.

After 2008, horror films further emphasize the themes of excessive female sensuality by presenting the cast of artists who sell sensuality. Like the film "Charisma" (2016), "Suster Keramas" (2010), "Suster Keramas 2" (2011), and "Rintihan Kuntilanak Perawan" (2010). Furthermore, horror films from 2010-2019 are still being produced, it is recorded from the report of the creative economy agency (Bekraf). In 2019 (Yustriani \& Rahman, 2019) that horror films are one of the three leading genres that are widely produced and watched by Indonesians. From Bekraf's Calculations, 2016 was recorded with a percentage of $16 \%$ of the production of the Indonesian horror film genre and "The Doll" as a horror film with more than 3 million views. In 2017, 21\% of horror films were screened and put "Pengabdi Setan" as the most-watched film this year, and the success of "Danur". In 2018, the percentage of production and screenings in theaters was $31 \%$, and placed the film "Suzanna" as the second highest number of films with more than 3 million viewers throughout 2018. The journey of horror films in Indonesia has experienced ups and downs. several things are not noticed in Indonesian horror films, namely paying less attention to the creative aspects of the story, but more on 
storylines, cinematography, and repetitive appearances, and seem repetitive in terms of the story from year to year (Tiwahyupriadi \& Ayuningtyas, 2020).

\section{The Sacralization of the Myth of Prohibition of Leaving at Dusk in Sandekala Film}

Sacralization can be understood from the origin of the word 'sacred'. Sacred is defined as something that is purified, sanctified, protected from violation, disturbance, or pollution. According to (Nurdinah, 2013), things that can be sacred are objects, holy places, and religious holy days. sacred objects in Islam such as the Qur'an, Tanah Haram, Waliyullah, and the Ka'bah. The holy places are sacred in Islam are in the form of mosques, prayer rooms, and the Ka'bah. The holy days are sacred in Islam include the Islamic holidays and the month of Ramadan. Sacred is an adjective, which is defined as to sanctify, purify objects, holy places, and religious holy days.

Sacralization also applies to the myths of society. myths were created by society as a means of understanding themselves and their relationship with the universe, before determining the actions and attitudes to be carried out. myths want to explain phenomena that exist in the natural environment that are difficult to reach by the human mind or ratio. Therefore, myth is communicated through symbols, symbols, legends, fairy tales of a phenomenon that cannot be reached by reason. According to (Iswidayati, 2007), myth has two functions, namely: as a means of education and as an stimulant for creativity and new thinking. The function of myth as a means of education can be interpreted as a moral message, maintaining cultural nobility and strengthening social systems. For example, such as the tale of Malin Kundang, the role of myth here is as a means of communicating fairy tales from west sumatra about parental relationships, and the consequences for disobedient children. There is also a fairy tale about Dewi Sri. Meanwhile, myth also functions as a stimulant for creativity and new thinking. The function of this myth is to convey transformative messages that can be integrated into one myth, or it can also be manifested in a new version of the same myth. Filmmakers widely uses the function of myth as a stimulant for creativity and new thinking, or creative workers in the field of film and content creators on social media (Hasan, 2020) to adapt stories from community myths. myths can be used as commodities for the film industry.

The prohibition to leave the house at dusk has been mentioned in the hadiths of Imam Bukhari (3280) and Imam Muslim (2012) with the top narrator, Jabir bin Abdillah. 
The hadith that prohibits leaving the house at dusk or sunset is a manifestation of the study of living hadith in Indonesia, namely how a community interprets the presence or existence of hadith according to social events in a particular Muslim community, especially in Java and Sunda. Apart from being in the hadith, and being included in the study of living hadith, the prohibition of leaving the house at sunset is also local wisdom. Sundanese, Javanese and Malay local wisdom has been around for a long time, then it is practiced and passed down from several generations from generation to generation. Groups or communities of residents who believe in the prohibition of going out at sunset hardly have time to question or realize the origin of local wisdom (Kurniawan, 2019). So that the prohibition of going out at sunset which is a myth in Indonesian society and becomes sacred. The process of sacredening myths, this belief is called sacralization (Debby et al., 2020). This myth is sanctified or respected because there is an inner feeling, a sense of fear, and a sense of wanting to avoid danger. This link between the myth of the prohibition of leaving sunset by the community, religious symbols, and the fear of demons is deliberately targeted by the film director Sandekala to be made into a horror film so that it is easier to dramatize it in a horror film.

After conducting observations in Sandekala Film, some scenes are found about the dusk (Magrib) myth sacralization presented in the following table:

Table 1. The sound of prayer call (adzan) and the dark sky

\begin{tabular}{|c|l|l|l|}
\hline SHOT & \multicolumn{1}{|c|}{ VISUAL } & TEXT/DIALOGUE & \multicolumn{1}{|c|}{ NOTES } \\
\hline ELS & $\begin{array}{l}\text { Maghrib (dusk) prayer call and } \\
\text { views of housing silhouettes } \\
\text { and views of the dark sky } \\
\text { indicated that maghrib (dusk) } \\
\text { has arrived. }\end{array}$ & & $\begin{array}{l}\text { Cast:- } \\
\text { Scene: } \\
1 \text { (residential area) in the } \\
\text { afternoon. } \\
\text { Effect: maghrib (dusk) prayer } \\
\text { call sound. }\end{array}$ \\
\hline
\end{tabular}

Table 2. A mother who asks her children to go home

\begin{tabular}{|l|l|l|l|}
\hline SHOT & \multicolumn{1}{|c|}{ VISUAL } & \multicolumn{1}{|c|}{ TEXT/DIALOGUE } & \multicolumn{1}{c|}{ NOTES } \\
\hline LS & $\begin{array}{l}\text { A mother who asked her child } \\
\text { to go home means that maghrib } \\
\text { (dusk) had arrived. }\end{array}$ & $\begin{array}{l}\text { Ibu: Hey, it is } \\
\text { maghrib! Go in! }\end{array}$ & $\begin{array}{l}\text { Cast:- } \\
\text { Scene: } \\
2 \text { (residential area) in the } \\
\end{array}$ \\
& & & $\begin{array}{l}\text { afternoon. } \\
\text { Effect: maghrib (dusk) prayer } \\
\text { call sound. }\end{array}$ \\
\hline
\end{tabular}

Table 3. A man who is going to the mosque

\begin{tabular}{|l|l|l|l|}
\hline SHOT & \multicolumn{1}{|c|}{ VISUAL } & TEXT/DIALOGUE & \multicolumn{1}{c|}{ NOTES } \\
\hline LS & A middle-aged man who & & Cast: A middle-aged man, an extra \\
& was about to go to the & & from a shop seller, and an extra from \\
& mosque. & & a child entering the house. \\
& & Scene: \\
& & 5 (residential area) in the afternoon. \\
\hline
\end{tabular}




\begin{tabular}{|l|l|l|l|}
\hline & & $\begin{array}{l}\text { Effect: maghrib (dusk) prayer call } \\
\text { sound. }\end{array}$ \\
\hline
\end{tabular}

Table 4. People who are getting ready to pray

\begin{tabular}{|c|l|l|l|}
\hline SHOT & \multicolumn{1}{|c|}{ VISUAL } & TEXT/DIALOGUE & \multicolumn{1}{c|}{ NOTES } \\
\hline CS & $\begin{array}{l}\text { People who were getting } \\
\text { ready to do maghrib (dusk) } \\
\text { prayer at the mosque }\end{array}$ & & $\begin{array}{l}\text { Cast: 3 extras who were getting } \\
\text { ready to do maghrib (dusk) prayer at } \\
\text { the mosque } \\
\text { Scene: } \\
6 \text { (mosque) in the afternoon }\end{array}$ \\
& & & \\
\hline
\end{tabular}

Table 5. A mother who forces her child to go through the road they used to walk

\begin{tabular}{|c|l|l|l|}
\hline SHOT & \multicolumn{1}{|c|}{ VISUAL } & TEXT/DIALOGUE & \multicolumn{1}{c|}{ NOTES } \\
\hline MCU & $\begin{array}{l}\text { A mother forced her child to } \\
\text { go through the road they } \\
\text { used to walk, but suddenly } \\
\text { a kuntilanak ghost } \\
\text { appeared. }\end{array}$ & $\begin{array}{l}\text { Mother: We should } \\
\text { go this way. } \\
\text { Mother: Let us go }\end{array}$ & $\begin{array}{l}\text { Cast: A mother and her child. } \\
\text { Scene: } \\
\text { 13 (at the crossroads). In the } \\
\text { afternoon, it is dusk (maghrib). }\end{array}$ \\
\hline
\end{tabular}

After the writer observed, saw and heard the film elements in the Sandekala film, finally the data are found in shots, visuals, dialogues and information related to the issues raised in this paper. The next step is to analyze the film using Charles Sanders Peirce's Semiotics to obtain data findings in the form of scene fragments from the scene used to describe Peirce's semiotics about the meaning of a sign. The main point of Charles Sanders Peirce's Semiotics is the trichotomy which consists of three levels and subtypes of signs.

From those signs, the researcher describes the signs in the Sandekala film scenes. The following is a description of the results of the research that have been analyzed:

Table 6. Scene 1

\begin{tabular}{|l|l|l|}
\hline Sign/Texts & Object & $\begin{array}{l}\text { Interpretant } \\
\text { prayer being echoed is a } \\
\text { sign that it is time for } \\
\text { maghrib prayer. }\end{array}$ \\
$\begin{array}{l}\text { Scene } 1 \\
\text { The view of the sky was getting } \\
\text { dark accompanied by the sound of } \\
\text { maghrib prayer call. }\end{array}$ & $\begin{array}{l}\text { The meaning of this sign is a sign of } \\
\text { of a dark atmosphere. }\end{array}$ \\
\hline
\end{tabular}

This sign is in scene 1 . The scene explains that the call to prayer is a call or a call to Muslims who have entered at dusk. The sign in this scene is the call to prayer being pronounced. The adzan here is also closely related to the fifth pillar of Islam, namely 
prayer. So the call to prayer here is an essential component in the inclusion of prayer times. This sign is a sinign, a sign that is a sign based on shape or appearance in reality. This scene aims to call on the Muslim community to enter prayer times, temporarily leave their activities, and carry out worship.

Table 7. Scene 2

\begin{tabular}{|l|l|l|}
\hline Sign/Text & Object & Interpretant \\
\hline & $\begin{array}{l}\text { In this scene, a mother } \\
\text { reminded her child to } \\
\text { immediately go into the house, } \\
\text { because it was getting dark. }\end{array}$ & $\begin{array}{l}\text { The meaning of this sign is that when it is } \\
\text { already dusk, do not play or do activities } \\
\text { outside the house. }\end{array}$ \\
$\begin{array}{l}\text { Scene 2 } \\
\text { Residential people and a } \\
\text { mother who reminded her } \\
\text { child. } \\
\text { Dialogue: }\end{array}$ & \\
"Hey, it is maghrib, come \\
in!"
\end{tabular}

A mother told her child to go into the house because it was getting late immediately. The dialogue is in scene 2 . This scene tells about children playing outside the house and when sunset begins, a mother orders her child to come in. Sign in this scene is a mother's cry or warning to her child to enter the house immediately. This also relates to the hadith of the Prophet, not to do activities outside the home when maghrib approaches. This sign is a sinign, a sign that is a sign based on shape or appearance in reality. When it gets dark or dusk begins to come, the purpose of this scene is to do not do activities outside the house. This is also stated in the hadith of the Prophet because the demons came out at that time.

Table 8. Scene 5

\begin{tabular}{|c|c|c|}
\hline Sign/Text & Object & Interpretant \\
\hline $\begin{array}{l}\text { Scene } 5 \\
\text { A middle-aged man, wearing a cap, } \\
\text { sarong and koko shirt. }\end{array}$ & $\begin{array}{l}\text { A man who is walking } \\
\text { to go to the mosque. }\end{array}$ & $\begin{array}{l}\text { The meaning of this sign is a } \\
\text { recommendation to pray in congregation } \\
\text { at the mosque. }\end{array}$ \\
\hline
\end{tabular}

This scene is in scene 5 . The scene shows a middle-aged man wearing Muslim clothes to go to the mosque. Sign in this scene is a man wearing Muslim clothes, complete with sarong, cap and prayer mat. The man was about to go to the mosque 
when the call to prayer rang out. This sign is a sinsign, which is a sign that is a sign based on shape or appearance in reality. The purpose of this sign is a recommendation to pray in the congregation at the mosque.

Table 9. Scene 6

\begin{tabular}{|l|l|l|}
\hline Sign/Text & Object & Interpretant \\
\hline & $\begin{array}{l}\text { Showing several people } \\
\text { who are getting ready } \\
\text { to pray in congregation } \\
\text { at the mosque. }\end{array}$ & $\begin{array}{l}\text { The meaning of this sign is the } \\
\text { atmosphere of the Maghrib prayer in } \\
\text { congregation at the mosque. }\end{array}$ \\
$\begin{array}{l}\text { Scene 6 } \\
\text { People who were at the mosque. }\end{array}$ & \\
\hline
\end{tabular}

This scene is in scene 6, in this scene you can see several people who are getting ready to pray in congregation at the mosque. The sign in this scene is a person in the mosque, who is getting ready to pray in the congregation. This sign is a sinsign, which is a sign that is a sign based on shape or appearance in reality. The purpose of this scene is the atmosphere of evening prayer in the congregation.

Table 9. Scene 13

\begin{tabular}{|l|l|l|}
\hline Sign/Text & Object & Interpretant \\
\hline & $\begin{array}{l}\text { The mother told her } \\
\text { child to go through the } \\
\text { road they used to walk. } \\
\text { However, suddenly a } \\
\text { kuntilanak } \\
\text { appeared. }\end{array}$ & $\begin{array}{l}\text { The meaning of this sign explains that not } \\
\text { come out at dusk, because the devil } \\
\text { appears at that time. }\end{array}$ \\
$\begin{array}{l}\text { Scene 13 facial } \\
\text { expressions and shocked } \\
\begin{array}{l}\text { Dialog: } \\
\text { Mother: "We have to go this way." } \\
\text { Mother: "Cmon!" }\end{array}\end{array}$ \\
\hline
\end{tabular}

The dialogue is in scene 13 , in this scene it is told, a mother who is worried because of her confusion cannot get out of the crossroads. Moreover, when the mother decided to take the path they used to take, suddenly a kuntilanak ghost appeared. The sign in the scene is the facial expression in the scene of the mother telling her child to go through the path they usually take. The expression on the child's face was shocked when the kuntilanak ghost appeared. This sign is a sinign, a sign that is a sign based on shape or appearance in reality. The purpose of this sign is not to come out at dusk, because the devil appears at that time.

The results of observations and analysis of all scenes, the depiction of the sacredness of the prohibition of leaving sunset is undeniable, and presented as it is, 
following the myth that developed in society "Yen Waktu Maghrib aja Metu Saka Omah Mundhak Ono Sambikolo," and according to the hadith of the Prophet narrated by Imam Bukhari ( 3280) and Imam Muslim (2012). This local and religious myth does not have an element of dramatization that is included in the long dialogue, and additional dialogues from other figures are only the first and second characters. The depiction of the sacredness of the myth of the prohibition of going out at sunset in this film with a dark evening scene, the mother and child as the main characters who have left the house at dusk ignoring the prohibition that has become a myth of society. This film confirms the community's myth about demons hovering around at dusk, as evidenced by the appearance of a ghost in the last scene. This Sandekala film seeks to make the myth of prohibiting going out of the house at sunset, and also to target the segmentation of young people and urbanites who have begun to forget this myth.

\section{Conclusion}

This paper discusses the sacralization of the myth of the prohibition to leave the house at sunset in the horror film of Sandekala, from the analysis, myth and religion are a theme that is very close to society, and horror films themselves always explore fear, anxiety and test the adrenaline that is presented from a combination of dark scenes a gripping voice and dialogue that portrays the fear of the cast. The Sandekala film combines mythological and religious themes which are deliberately combined to become a film commodity. This film is also an attempt to bring back the myth of the prohibition of leaving the house for a moment at dusk which is intended for the segmentation of young and urban audiences. This myth has only been circulating from generation to generation in villages, Javanese, Sundanese, and several regions in Indonesia but is starting to fade to the belief of urban people.

\section{References}

Agustina, W. L. (2016). Mitos dan Sensualitas Dalam Perkembangan Film Horor Indonesia. Patrawidya: Seri Penerbitan Penelitian Sejarah Dan Budaya, 17, 193-208. http://patrawidya.kemdikbud.go.id/index.php/patrawidya/article/view/61/49

Ayun, P. Q. (2015). Sensualitas dan Tubuh Perempuan dalam Film-film Horor di Indonesia (Kajian Ekonomi Politik Media). JURNAL SIMBOLIKA: Research and Learning in Communication Study, 1(1). 
http://www.ojs.uma.ac.id/index.php/simbolika/article/view/46

cnbcindonesia.com. (2019). Ngeri, Ini Cuan Besar di Balik Industri Film Horor RI! https://www.cnbcindonesia.com/lifestyle/20191113161031-33-115033/ngeriini-cuan-besar-di-balik-industri-film-horor-ri

cnnindonesia.com. (2019). Rupiah, "Buah Manis" dari Seram Film Horor. https://www.cnnindonesia.com/hiburan/20191027180653-220-443285/rupiahbuah-manis-dari-seram-film-horor

Debby, Y., Hartiana, T. I. P., \& Krisdinanto, N. (2020). Desakralisasi film horor Indonesia dalam kajian reception analysis. ProTVF, 4(1), 1. https://doi.org/10.24198/ptvf.v4i1.24171

Farizal Alam, Z. Q. (2018). Hadis dan Mitos Jawa. Riwayah : Jurnal Studi Hadis, 3(1), 109. https://doi.org/10.21043/riwayah.v3i1.3440

FilmFest, J. (2016). Penghargaan Film Sandekala. https://jaff-filmfest.org/open-aircinema/sandekala/

Hakim, L. (2017). AGAMA \& FILM (Pengantar Studi Film Religi). Government of Indonesia (GoI) and Islamic Development Bank (IDB).

Hasan, N. (2020). KONSTRUKSI STIGMA MISTIS KOTA BANYUWANGI DALAM CERITA KKN DI DESA PENARI. MUHARRIK: Jurnal Dakwah Dan Sosial, 3(02), 139-156. https://doi.org/10.37680/muharrik.v3i02.434

Herawati, E. (2011). Pornografi dalam Balutan Film Bertema Horor Mistik di Indonesia. Humaniora, 2(2), 1408. https://doi.org/10.21512/humaniora.v2i2.3209

Ida, R. (2014). Metode Penelitian: Studi Media dan Kajian Budaya. Jakarta : Prenadamedia Group.

Iswidayati, S. (2007). Fungsi Mitos Dalam Kehidupan Sosial Budaya Masyarakat. Harmonia: Jurnal Pengetahuan Dan Pemikiran Seni, VIII(2), 180-184. https://media.neliti.com/media/publications/64751-ID-none.pdf

Kriyantono, R. (2014). Teknis Praktis Riset Komunikasi (7th ed.). Jakarta : Kencana Prenadamedia.

Kurniawan, S. (2019). PANTANG LARANG BERMAIN WAKTU MAGRIB: Kajian Living Hadis Tradisi Masyarakat Melayu Sambas. Jurnal Living Hadis, IV(1), 1-26. https://doi.org/10.14421/livinghadis.2019.1629

Marwantika, A. I. (2019). Potret dan Segmentasi Mad'u Dalam Perkembangan Media di Indonesia. Al-Adabiya: Jurnal Kebudayaan Dan Keagamaan, 14(01), 1-14. 
https://doi.org/10.37680/adabiya.v14i01.100

Nur, A. (2016). Perayaan Mitos Dalam Film Horor Indonesia: Analisa Struktural dan Implikasi Sosial. Al-Ibrah, 1(1), 140-169.

Nurdinah, M. (2013). Memahami Konsep Sakral dan Profan Dalam Agama-Agama. In Substantia: Jurnal Ilmu-Ilmu Ushuluddin (Vol. 15, Issue 2).

Sobur, A. (2008). Semiotika Komunikasi. BAndung : Remaja Rosdakarya.

Tiwahyupriadi, D., \& Ayuningtyas, Y. (2020). Indonesian Horror Film : Deconstruction of Repetitive Elements of Indonesian Urban Legend for Cultural Revitalization, Creativity, and Critical Thinking. 2020, 115-125. https://doi.org/10.18502/kss.v4i12.7589

Wahyuningsih, S. (2019). Film \& Dakwah : Memahami Representasi Pesan-Pesan Dakwah Dalam Film Melalui Analisis Semiotika. Surabaya : Media Sahabat Cendekia.

Watkins, G. J. (2008). Teaching Religion and Film. Oxford University Press.

Yoesoef, M. (2015). Film Horor Sebuah Definisi yang Berubah. Wacana, Journal of the Humanities of Indonesia, 5(2), 1. https://doi.org/10.17510/wjhi.v5i2.322

Yustriani, L., \& Rahman, L. (2019). Analisis Data Kajian Pemandangan Umum Industri Film 2019. BEKRAF (Badan Ekonomi Kreatif). https://www.bekraf.go.id/pustaka/page/pemandangan-umum-industri-filmindonesia-2019 